\title{
HUBUNGAN AKTIVITAS FISIK, ASUPAN ENERGI DAN STRES DENGAN KADAR GLUKOSA DARAH PUASA MAHASISWA FKIP JURUSAN PENJASKESREK UNIVERSITAS HALU OLEO KOTA KENDARI TAHUN 2019
}

\author{
Fifi Nirmala $\mathbf{G}^{1}$ Deka Wahyuni ${ }^{2}$ Paridah $^{3} \quad$ Farid Rezal $^{4}$ \\ 1,2,3 Fakultas Kesehatan Masyarakat Universitas Halu Oleo Kendari \\ ${ }^{1}$ Fifinirmala87@Gmail.com2deka.wahyuni98@gmail.com 3/dha.Paridah@yahoo.co.id \\ 4faritrezz@gmail.com
}

\begin{abstract}
Abstrak
Penumpukan kadar gula dalam darah merupakan salah satu penyebab terjadinya penyakit diabetes melitus. Aktivitas fisik yang dilakukan oleh seseorang akan mempengaruhi kadar glukosa darahnya. Faktor yang mempegaruhi glukosa darah puasa tidak terkendali adalah pengetahuan, pendidikan, diet, stres, asupan makan, kurang aktivitas fisik, asupan obat yang berhubungan dengan pengendalian kadar gula darah. Tujuan dari penelitian ini adalah untuk mengetahui hubungan aktifitas fisik, asupan energi dan stres dengan kadar glukosa darah puasa mahasiswa Fakultas Keguruan Ilmu Pengetahuan Jurusan Penjaskesrek kota Kendari di Universitas Halu Oleo. Jenis penelitian ini adalah analitik dengan menggunakan pendekatan cross sectional. Jumlah sampel adalah sebanyak 120 orang yang dipilih dengan menggunakan teknik purposive sampling. Analisis yang digunakan yakni analisis bivariat dengan menggunakan uji chi square. Hasil penelitian menunjukan bahwa terdapat Hubungan aktivitas fisik dengan kadar glukosa darah puasa ( $p$ value 0,000), tidak ada hubungan asupan energi dengan kadar glukosa darah puasa ( $p$ value 0,656) dan tidak ada hubungan stres dengan kadar glukosa darah puasa ( $p$ value 0,510). Sehingga dapat disimpulkan dari hasil tes menunjukan aktivitas fisik dapat menyebabkan glukosa darah puasa. Glukosa akan diubah menjadi energi pada saat beraktivitas fisik. Aktivitas fisik mengakibatkan insulin semakin meningkat sehingga kadar gula dalam darah akan berkurang. Dengan beraktivitas fisik maka banyak manfaat untuk menurunkan stres.
\end{abstract}

Kata Kunci: Aktivitas fisik, Asupan energi, dan Stres dengan Kadar glukosa darah puasa

\begin{abstract}
Stacking blood sugar levels is one of the causes of diabetes mellitus. Physical activity by a person affects the blood glucose level. The factors that promote the fasting blood glucose uncontrolled are knowledge, education, diet, stres, dietary intake, lack of physical activity, intake of drugs related to the control of blood sugar levels. The purpose of this research is to know the relationship of physical activity, energy intake and stress with the fasting blood glucose level students Faculty of Teaching Sciences Department of Kendari. This type of research is analytic using a cross sectional approach. The sample number is 120 people selected using the purposive sampling technique. The analysis used is bivariate analysis using Chi Square test. The results showed that there is physical activity relationship with fasting blood glucose level ( $p$ value 0.000 ), there is no energy intake connection with fasting blood glucose level ( $p$ value 0.656 ) and no stress connection with fasting blood glucose levels ( $p$ Value 0.510 ). So that can be deduced from the test results showed physical activity can cause fasting blood glucose. Glucose will be converted into energy during physical activity. Physical activity results in insulin increasing so that the blood sugar levels will be reduced. With physical activity, many benefits for lowering stres.
\end{abstract}

Keywords: physical activity, energy intake, and stress with fasting blood glucose levels 


\section{PENDAHULUAN}

Glukosa darah yang lebih tinggi dari batas maksimum mengakibatkan tambahan 2,2 juta kematian, dengan meningkatkan risiko penyakit kardiovaskular dan lainnya. Empat puluh tiga persen (43\%) dari 3,7 juta kematian ini terjadi sebelum usia 70 tahun. Persentase kematian yang disebabkan oleh diabetes yang terjadi sebelum usia 70 tahun lebih tinggi di negara-negara berpenghasilan rendah dan menengah daripada di negara-negara berpenghasilan tinggi ${ }^{1}$.

Glukosa Darah Puasa (GDP) adalah glukosa darah seseorang yang diperiksa setelah menjalani puasa selama 10-12 jam. Kadar Glukosa Darah Puasa menjadi salah satu pedoman dalam melakukan diagnosis Diabetes Mellitus. Jika hasil pemeriksaan kadar Glukosa Darah Puasa $\geq 126$ $\mathrm{mg} / \mathrm{dl}$ dan terdapat keluhan khas Diabetes Mellitus, diagnosis Diabetes Mellitus dapat ditegakkan. Dengan demikian, kadar Glukosa Darah Puasa yang buruk adalah kadar Glukosa Darah Puasa $\geq 126$ $\mathrm{mg} / \mathrm{dl}$ atau dalam penelitian akan disebut se-bagai Glukosa Darah Puasa tidak terkendali. Kondisi gula darah yang tidak ter-kendali dapat memicu timbulnya komplikasi akibat Diabetes Mellitus tipe $2^{2}$.

Penumpukan kadar gula dalam darah merupakan salah satu penyebab terjadinya penyakit diabetes melitus. Kadar gula darah yang tinggi dan tidak dapat terkontrol dalam jangka waktu yang lama dapat menimbulkan beberapa komplikasi. Pada diabetes melitus, insulin yang tidak terkontrol meningkatkan konsentrasi gula dalam darah dan juga ketidakmampuan tubuh dalam memproduksi insulin memperberat kondisi tersebut, situasi ini dikenal sebagai hiperglikemia, sehingga kadar gula dalam darah yang tinggi tersebut akan mempengaruhi terjadinya kerusakan pada tubuh serta kegagalan berbagai jaringan dan organ. Pada orang non diabetes yang melakukan latihan fisik dengan teratur, memiliki tingkat toleransi insulin terhadap gula darah yang normal atau meningkat ${ }^{3}$.

Prevalensi diabetes mellitus yang semakin meningkat merupakan ancaman bagi kesehatan masyarakat pada umumnya. Diabetes mellitus adalah penyakit metabolisme yang disebabkan adanya peningkatan kadar glukosa darah di atas nilai normal. Adanya gangguan metabolisme glukosa ini akibat kekurangan insulin baik secara absolut maupun relatif. Jika dibandingkan dengan tahun 2013, prevalensi DM berdasarkan diagnosis dokter pada penduduk umur $\geq 15$ tahun hasil Riskesdas 2018 meningkat menjadi 2\%. Prevalensi DM berdasarkan diagnosis dokter dan usia $\geq 15$ tahun yang terendah terdapat di Provinsi NTT, yaitu sebesar 0,9\%, sedangkan prevalensi DM tertinggi di
Provinsi DKI Jakarta sebesar 3,4\%. Prevalensi DM semua umur di Indonesia pada Riskesdas 2018 sedikit lebih rendah dibandingkan prevalensi DM pada usia $\geq 15$ tahun, yaitu sebesar $1,5 \%$. Sedangkan provinsi dengan prevalensi DM tertinggi semua umur berdasarkan diagnosis dokter juga masih di DKI Jakarta dan terendah di NTT, Sedangkan prevalensi DM tertinggi di Provinsi DKI Jakarta sebesar 3,4\%. Pada tahun 2018, Sulawesi tenggara menempati urutan ke-14 penderita diabetes mellitus terbanyak di Indonesia ${ }^{4}$.

Faktor yang mempegaruhi glukosa darah puasa (GDP) tidak terkendali adalah pengetahuan, pendidikan, diet, stress, asupan makan, kurang aktivitas fisik, asupan obat yang berhubungan dengan pengendalian kadar gula darah. Hal ini dapat meningkatkan terjadinya resistensi insulin sehingga kadar gula darah tidak terkendali. Kondisi gula darah yang tidak terkendali dapat menyebabkan penyakit DM. Kadar gula di dalam darah tidak boleh lebih tinggi dari $180 \mathrm{mg} / \mathrm{dl}$ dan jangan lebih rendah dari $60 \mathrm{mg} / \mathrm{dl}$. Untuk mengatur hal ini tubuh mempunyai mekanisme pengaturannya. Apabila mekanisme ini tidak berjalan dengan baik maka akan terjadi penyakit diabetes mellitus.

Kadar glukosa darah bisa dikontrol untuk mencegah terjadinya kenaikan kadar gula darah yang bisa mengakibatkan diabetes melitus, setiap responden dapat melakukan pencegahan, dengan menghindari makanan yang bisa meningkatkan kadar gula darah seperti makanan yang mengandung karbohidrat yang tidak sehat, makanan yang manis dan atur pola makan yang baik yang dapat memberikan kadar gula darah yang baik. Agar kadar glukosa darah lebih stabil perlu melakukan gaya hidup yang sehat seperti melakukan aktivitas fisik yang teratur, usahakan makan teratur setiap hari dan atur jenis, jumlah, serta jadwalnya. Selain itu upaya penyuluhan dari petugas kesehatan atau puskesmas tentang pengaturan makan yang teratur (makan pagi, makan siang, makan malam) kepada masyarakat khususnya yang mengalami peningkatan kadar glukosa darah dan penurunan kadar glukosa darah. Dengan demikian kita bisa memperkirakan kapan dan bagaimana glukosa darah naik dan turun ${ }^{4}$.

Kadar glukosa darah biasanya turun setelah melakukan latihan fisik jika tubuh memiliki persediaan insulin yang cukup untuk memfasilitasi penggunaan glukosa oleh sel-sel tubuh. Latihan fisik dapat mempengaruhi kadar glukosa darah sampai 48 jam. Bila kadar glukosa darah sudah rendah sebelum melakukan latihan fisik, tubuh akan menarik simpanan glukosa berupa glikogen dalam hati dan otot untuk menyediakan energi. Setelah 
20-30 menit, simpanan energi ini akan sangat berkurang sehingga bila terlalu memaksakan diri, kadar gula darah akan segera naik. Setelah periode latihan yang terus-menerus dan pada tingkat yang tepat, kadar glukosa darah akan turun ${ }^{5}$.

Aktivitas fisik secara langsung berhubungan dengan kecepatan pemulihan gula darah otot. Saat aktivitas fisik, otot menggunakan glukosa yang disimpannya sehingga glukosa yang tersimpan akan berkurang. Pada saat itu untuk mengisi kekurangan tersebut otot mengambil glukosa di dalam darah sehingga glukosa di dalam darah menurun yang mana hal tersebut dapat meningkatkan kontrol gula darah $^{6}$.

Secara teori, melakukan aktifitas fisik atau berolahraga secara teratur dapat menurunkan dan menjaga kadar gula darah tetap normal. Prinsipnya, tidak perlu olahraga berat, olahraga ringan atau aktifitas fisik ringan akan sangat bagus pengaruhnya bagi kesehatan. Beberapa olahraga yang disarankan, antara lain jalan atau lari pagi, bersepeda, berenang dan lain sebagainya. Olahraga akan memperbanyak jumlah dan juga meningkatkan penggunaan glukosa ${ }^{7}$

Aktivitas fisik yang dilakukakan oleh seseorang akan mempengaruhi kadar gula darahnya. Peningkatan penggunaan glukosa oleh otot akan meningkat saat seseorang melakukan aktivitas fisik yang tinggi. Hal tersebut disebabkan glukosa endogen akan ditingkatkan untuk menjaga agar kadar gula di dalam darah tetap seimbang. Pada keadaan normal, keseimbangan kadar gula darah tersebut dapat dicapai oleh berbagai mekanisme dari sistem saraf, regulasi glukosa dan keadaan hormonal. 20 Teori lain menyebutkan bahwa aktivitas fisik secara langsung berhubungan dengan kecepatan pemulihan gula darah otot. Saat aktivitas fisik dilakukan, otot-otot di dalam tubuh akan bereaksi dengan menggunakan glukosa yang disimpannya sehingga glukosa yang tersimpan akan berkurang. Dalam keadaan tersebut akan terdapat reaksi otot yang mana otot akan mengambil glukosa di dalam darah sehingga glukosa di dalam darah menurun dan hal tersebut dapat meningkatkan kontrol gula darah ${ }^{8}$.

Asupan energi dapat diperoleh dari bahan makan yang mengandung karbohidrat, protein dan lemak. Asupan makanan tinggi energi (tinggi lemak dan gula) dan rendah serat berhubungan dengan kadar gula darah. Ketidakseimbangan antara asupan makanan yang tinggi energi dengan pengeluaran energi untuk aktivitas dalam jangka waktu lama memungkinkan terjadinya obesitas, resistensi insulin dan penyakit DM tipe $2^{9}$.

Stres merupakan faktor yang berpengaruh penting bagi penyandang diabetes peningkatan hormon stres diproduksi dapat menyebabkan Kadar Gula Darah menjadi meningkat. Kondisi yang rileks dapat mengembalikan kotra-regulasi hormon stres dan memungkinkan tubuh untuk menggunakan insulin lebih efektip. stres yang tinggi dapat memicu kadar gula darah dalam tubuh yang semakin meningkat. Stress menyebabkan produksi berlebih pada kortisol, kortisol adalah suatu hormon yang melawan efek insulin dan menyebabkan kadar glukosa darah tinggi. Jika seseorang mengalami stress berat yang dihasilkan dalam tubuhnya, maka kortisol yang dihasilkan akan semakin banyak, ini akan mengurangi sensifitas tubuh terhadap insulin. Kortisol merupakan musuh dari insulin sehingga membuat glukosa lebih sulit untuk memasuki sel dan meningkatkan glukosa darah ${ }^{10}$.

Faktor yang mempengaruhi keluarnya hormon adrenalin misalnya stres dan kadar lemak di bawah jaringan kulit dan di perut. Hormon adrenalin yang dipacu secara terus-menerus akan mengakibatkan insulin tidak bisa mengatur kadar gula darah yang ideal $^{11 .}$

\section{METODE}

Penelitian ini termasuk jenis penelitian bersifat observasional analitik dengan desain potong lintang (cross-sectional study). Rancangan penelitian yang digunakan adalah cross sectional. Studi cross sectional mengamati variabel dependen dan variabel independen dalam waktu yang bersamaan. Dalam penelitian ini variabel independennya adalah aktivitas fisik, variabel dependennya adalah kadar gula dara puasa dan variabel asupan energi, dan stres 
HASIL

Tabel 1 Responden menurut Umur, jenis kelamin, angkatan kelas pada Mahasiswa Fakultas Keguruan IImu Pendidikan Angkatan 2017-2018 Jurusan Penjaskesrek Kota Kendari tahun 2019.

\begin{tabular}{|c|c|c|c|}
\hline No. & Variabel & Jumlah (n) & Persentase (\%) \\
\hline \multirow[t]{6}{*}{1} & Umur & & \\
\hline & 18 & 5 & 4,2 \\
\hline & 19 & 27 & 22,5 \\
\hline & 20 & 59 & 49,2 \\
\hline & 21 & 28 & 23,3 \\
\hline & 22 & 1 & 8 \\
\hline
\end{tabular}

\begin{tabular}{clcc}
\hline \hline $\mathbf{2}$ & Jenis kelamin & & \\
\hline \hline & Laki-Laki & 87 & 72,5 \\
\hline \hline Perempuan & 33 & 27,5 \\
\hline
\end{tabular}

\begin{tabular}{cccc}
\hline \hline 2017 & 78 & 65,0 \\
\cline { 2 - 4 } & 2018 & 42 & 35,0 \\
\hline \hline Total & $\mathbf{1 2 0}$ & $\mathbf{1 0 0}$ \\
\hline \hline
\end{tabular}

Tabel 1 menunjukkan bahwa dari 120 responden, sebagian besar responden berusia 20 tahun yaitu sebanyak 59 responden $(49,2 \%)$, berusia 21 responden sebanyak 28 responden $(23,3 \%)$, berusia 19 tahun yaitu sebanyak 27 responden $(22,5 \%)$, dan yang paling sedikit responden berusia 22 tahun yaitu sebanyak 1 responden (8\%). jumlah responden laki-laki sebanyak 87 mahasiswa $(72,5 \%)$, dan jumlah responden perempuan sebanyak 33 mahasiswi (27,5\%). sebagian besar responden berasal dari angkatan kelas 2017 yaitu sebanyak 78 responden (62,0\%), sedangkan yang berasal dari angkatan 2018 yaitu sebanyak 42 responden $(35,0 \%)$.

Tabel 2 Hubungan Aktivitas Fisik, Asupan Energi dan stres dengan Glukosa Darah Puasa pada Mahasiswa Fakultas Keguruan dan IImu Pendidikan Angkatan 2017-2018 Jurusan Penjaskesrek Kota Kendari tahun 2019

\begin{tabular}{|c|c|c|c|c|c|c|c|c|}
\hline \multirow[t]{3}{*}{ No } & \multirow{3}{*}{ Variabel } & \multicolumn{4}{|c|}{ Glukosa Darah Puasa } & \multicolumn{2}{|c|}{ Total } & \multirow[t]{3}{*}{ p Value } \\
\hline & & \multicolumn{2}{|c|}{ Tidak beresiko DM } & \multicolumn{2}{|c|}{ Berisiko DM } & \multirow[b]{2}{*}{$\mathbf{n}$} & \multirow[b]{2}{*}{$\%$} & \\
\hline & & $\mathbf{n}$ & $\%$ & $\mathbf{n}$ & $\%$ & & & \\
\hline \multirow[t]{3}{*}{1} & Aktivitas Fisik & & & & & & & \\
\hline & Tidak berat & 8 & 34,8 & 15 & 85,2 & 23 & 100 & \multirow{2}{*}{0,000} \\
\hline & Berat & 93 & 95,9 & 4 & 4,1 & 97 & 100 & \\
\hline \multirow[t]{3}{*}{2} & Asupan Energi & & & & & & & \\
\hline & Tinggi & 34 & 81,0 & 8 & 19,0 & 42 & 100 & \multirow{2}{*}{0,656} \\
\hline & Rendah & 67 & 85,9 & 11 & 14,1 & 78 & 100 & \\
\hline \multirow[t]{4}{*}{3} & Stres & & & & & & & \\
\hline & Tidak stres & 54 & 87,1 & 8 & 12,9 & 62 & 100 & \multirow{2}{*}{0,510} \\
\hline & Stres & 47 & 48,8 & 11 & 19,0 & 58 & 100 & \\
\hline & Total & 101 & 84,2 & 19 & 63,3 & 120 & 100 & \\
\hline
\end{tabular}

Sumber: Data Primer, Desember 2019.

Tabel 2 hasil penelitian menunjukkan bahwa dari 120 (100\%) responden, terdapat 101 (84,2\%) responden yang memiliki kadar glukosa darah puasa tidak berisiko dan terdapat 19 (63,3\%) responden yang memiliki kadar glukosa darah puasa berisiko. Hasil penelitian menunjukan bahwa variabel yang berhubungan dengan kadar glukosa darah puasa adalah aktivitas fisik ( $p$-value $=0,000$ ), variable yang tidak berhubungan dengan kadar 
glukosa darah puasa adalah asupan energi ( $p$-value $=0,656)$ dan stress ( $p$-value $=0,510)$.

\section{DISKUSI}

Hubungan Aktivitas Fisik dengan Kadar Glukosa Darah Puasa pada Mahasiswa Fakultas Keguruan Ilmu Pendidikan Angkatan 2017-2018 Jurusan Pendidikan Jasmani Kesehatan dan Rekreasi Universitas Halu Oleo Kendari Tahun 2019.

Berdasarkan Hasil penelitian ini uji statistik Chi-Square pada taraf kepercayaan 95\% $(0,05)$ menunjukkan bahwa $\rho$ Value $=0,000, \rho$ Value $<$ 0,05 , sehingga $H_{1}$ diterima dan $H_{0}$ ditolak, menunjukkan bahwa ada hubungan yang bermakna antara aktivitas fisik dengan kadar glukosa darah puasa pada mahasiswa angkatan 2017-2018 Fakultas Keguruan IImu Pendidikan jurusan Pendidikan Jasmani Kesehatan dan Rekreasi Universitas Halu Oleo Kota Kendari tahun 2018. Aktivitas fisik yang berat menyebabkan gula darah puasa rendah. Semakin beratnya aktivitas fisik, maka sumber energi yang dipakai akan semakin banyak. Hal ini menyebabkan gula darah akan banyak terpakai dan jumlah dalam darah menurun. Sehingga hasil pengukuran gula darah puasa akan didapatkan hasil yang rendah. Aktivitas fisik tadi mengakibatkan sensitivitas dari reseptor insulin semakin meningkat pula sehingga glukosa darah yang dipakai untuk metabolisme energi semakin banyak terpakai. Hal ini sesuai dengan teori bahwa Aktifitas fisik dan olahraga merupakan salah satu faktor yang cukup berperan penting dalam mempengaruhi nilai kadar glukosa darah ${ }^{12}$.

Hal tersebut diatas Sejalan dengan Hasil penelitian Intan Sahara (2017) yang menunjukkan adanya hubungan antara aktivitas fisik dan glukosa darah puasa. Aktivitas fisik yang berat menyebabkan gula darah puasa rendah. Semakin beratnya aktivitas fisik, maka sumber energi yang dipakai akan semakin banyak. Hal ini menyebabkan gula darah akan banyak terpakai dan jumlah dalam darah menurun. Sehingga hasil pengukuran gula darah puasa akan didapatkan hasil yang rendah. Aktivitas fisik tadi mengakibatkan sensitivitas dari reseptor insulin semakin meningkat pula sehingga glukosa darah yang dipakai untuk metabolisme energi semakin banyak terpakai ${ }^{13}$.

Secara teori dijelaskan bahwa pada saat keadaan istirahat metabolisme otot hanya sedikit menggunakan glukosa darah sebagai sumber energi, sedangkan pada saat beraktivitas fisik (latihan fisik / olahraga), otot menggunakan lemak dan glukosa darah sebagai sumber energi utama. Sel-sel otot mampu menyimpan glukosa dalam jumlah terbatas dalam bentuk glikogen otot, kemudian sampai tahap tertentu hati dapat menyimpan kelebihan glukosa dalam bentuk glikogen di dalam hepar (hati). Namun, setelah simpanan di hati dan otot penuh, kelebihan karbohidrat yang masuk akan diubah menjadi asam lemak. Asam lemak bam akan digunakan ketika terjadi pemecahan lemak menjadi sumber energi (glukoneogenesis) akibat meniminya asupan glukosa atau terjadi peningkatan kebutuhan glukosa. Peningkatan kebutuhan glukosa biasanya terjadi pada saat di lakukan aktivitas fisik khususnya aktivitas fisik yang berat misalnya pada olahragawan yang melakukan latihan fisik yang rutin dan memerlukan banyak energi ${ }^{14}$.

Hubungan Asupan Energi dengan Kadar Glukosa Darah Puasa pada Mahasiswa Fakultas Keguruan Ilmu Pendidikan Angkatan 2017-2018 Jurusan Penjaskesrek Universitas Halu Oleo Kendari Tahun 2019.

Berdasarkan Hasil uji statistik Chi-Square pada taraf kepercayaan $95 \%(0,05)$ menunjukkan bahwa $\rho$ Value $=0,479$ jadi $\rho$ Value $<0,05$, sehingga $\mathrm{H} 1$ diterima dan $\mathrm{HO}$ ditolak, menunjukkan bahwa tidak ada hubungan yang bermakna antara asupan energi dengan kadar glukosa darah puasa pada mahasiswa Fakultas Keguruan IImu Pendidikan Angkatan 2017-2018 Jurusan Pendidikan Jasmani Kesehatan dan Rekreasi angkatan 2017-2018 Kendari tahun 2019.

Hasil penelitian ini tidak sejalan dengan hasil penelitian Sindhu Nugroho Mukti (2014) yang berjudul hubungan aktivitas fisik dan asupan energi terhadap tekanan darah dan kadar glukosa darah pada mahasiswa fakultas kedokteran Penelitian ini merupakan penelitian observasional dengan pendekatan cross sectional. Subjek adalah 30 orang mahasiswa fakultas kedokteran Universitas Diponegoro tingkat pertama yang memenuhi kriteria inklusi, dipilih melalui simple random sampling menunjukkan bahwa terdapat hubungan yang bermakna antara asupan energi terhadap kadar glukosa darah $(p=0,031)$. Nilai $r=0,407$ artinya bahwa asupan energi berkorelasi secara positif terhadap kadar glukosa darah pada mahasiswa fakultas kedokteran Universitas Diponegoro. Dimana sampel dalam penelitian ini adalah mahasiswa fakultas kedokteran yang jarang melakukan aktivitas fisik ${ }^{15}$.

Sedangkan penelitian ini tidak ada hubungan asupan energi dengan kadar glukosa darah puasa. Dimana sampel dalam penelitian ini adalah mahasiwa jurusan penjaskesrek yang rutin melakukan aktivitas fisik berat atau melakukan olahraga. Kurangnya aktivitas fisik menimbulkan berbagai kerugian dalam tubuh. Aktivitas fisik 
mempunyai banyak manfaat, salah satunya adalah menjaga komposisi tubuh. Meningkatkan aktivitas fisik dapat mengurangi kadar glukosa darah yang tinggi atau beresiko. Cadangan asupan energi di dalam tubuh sebagai tambahan energi ketika kita melakukan aktivitas yang lebih, seperti berolahraga rutin, berlari, sepakbola, basket, dan lain-lain. Asupan energi yang tinggi dan rutin melakukan aktifitas fisik yang berat menyebabkan glukosa darah puasa bisa terkontrol ${ }^{16}$.

Gerakan anggota tubuh akibat kontraksi dan relaksasi otot skelet memerlukan energi. Tingkat aktivitas fisik erat kaitannya terhadap energi yang dikeluarkan tubuh. Aktivitas fisik dapat ditingkatkan dengan cara berolahraga. Semakin tinggi aktivitas fisik semakin banyak energi yang akan dikeluarkan oleh tubuh. Sumber energi utama yang digunakan dalam melakukan aktivitas adalah energi yang berasal dari makanan, tetapi jika energi yang berasal dari makanan sudah habis, tubuh akan mengkompensasi dengan memetabolisme energi yang berada di dalam tubuh. Jika hal ini terjadi secara terus menerus, maka kadar glukosa darah puasa di dalam tubuh akan berkurang secara berkala. Aktivitas merupakan salah satu faktor resiko utama terjadinya glukosa darah puasa yang tinggi atau beresiko, terlebih kemajuan teknologi di berbagai bidang mendorong masyarakat untuk melakukan kegiatan serba praktis dan tidak memerlukan kerja fisik berat. Terjadinya ketidakseimbangan antara energi yang masuk dan energi yang keluar inilah yang menyebabkan terjadinya glukosa darah puasa yang tinggi atau beresik $^{17}$.

\section{Hubungan Stres dengan Kadar Glukosa Darah Puasa pada Mahasiswa Fakultas Keguruan IImu Pendidikan Angkatan 2017-2018 Jurusan Penjaskesrek UHO Kendari Tahun 2019.}

Hasil uji statistik Chi-Square pada taraf kepercayaan $95 \%(0,05)$ menunjukkan bahwa $\rho$ Value $=0,510, \rho$ Value $<0,05$, sehingga Ho diterima dan $\mathrm{H}_{1}$ ditolak, menunjukkan bahwa tidak ada hubungan yang bermakna antara tingkat stres dengan kadar glukosa darah puasa pada mahasiswa Penjaskesrek angkatan 2017-2018 Kendari tahun 2018.

Penelitian ini sejalan yang dilakukan oleh Cecep Suhadi et al.,(2020). Penelitian ini dilakukan untuk mengetahui hubungan tingkat stres terhadap kadar glukosa darah pada manusia normal (tidak mengidap kelainan regulasi glukosa darah) dengan rentang umur 19-22 tahun. Metode pada penelitian ini menggunakan pendekatan Cross Sectional. Pengecekan tingkat stres menggunakan instrumen DASS 42 yang telah divalidasi ulang serta glucometer untuk mengukur kadar gula darah. Diperoleh nilai signifikansi Pearson Chi-Square $>0,05$ yang menunjukan tidak terdapat hubungan yang signifikan antara tingkat stres dengan kadar glukosa darah. Namun, terdapat resiko peningkatan kadar glukosa darah sebesar 1,714 kali lipat pada relawan dengan tingkat stres yang tinggi dibandingkan dengan relawan dengan tingkat stres yang normal.

Penelitian ini tidak sejalan dengan yang dilakukan oleh Amiruddin et al., (2014) menunjukkan ada hubungan stres dengan kadar glukos darah puasa pasien Diabetes Mellitus tipe 2 $(p=0,021)$. Proporsi kejadian DM tipe 2 adalah 1,43 kali lebih banyak pada mereka yang stress dibandingkan dengan mereka yang tidak stress. Penelitian yang sama juga dilakukan oleh Shiju et al., (2013) menunjukkan bahwa orang yang mengalami stress memiliki risiko 1,53 kali untuk menderita Diabetes Mellitus tipe 2 dibandingkan dengan orang yang tidak mengalami stress. Keadaan penelitian diatas menjelaskan adanya hubungan stres dengan glukosa darah puasa pada pasien diabetes mellitus. Dimana sampel penelitian ini adalah pasien diabetes mellitus yang jarang melakukan aktivitas fisik ${ }^{18}$.

Sedangkan penelitian ini tidak ada hubungan stres dengan kadar glukosa darah puasa. Dimana sampelnya adalah orang sehat yaitu mahasiswa yang rutin (2-3 kali dalam seminggu) melakukan aktivitas fisik berat atau melakukan olahraga. Dengan beraktivitas fisik maka banyak manfaat untuk menurunkan stres. Hal ini terkait dengan penurunan hormon-hormon stres saat berolahraga. Olahraga rutin dapat menurunkan kadar hormon epinefrin dan kortisol. Hormon-hormon tersebut yang disebut juga sebagai hormon stres akan meningkat saat tubuh menghadapi suatu stresor. Saat seseorang berolahraga atau melakukan aktivitas fisik secara rutin maka tubuh akan memproduksi beta-endorfin yang memiliki efek memperbaiki suasana hati sekaligus menurunkan hormon kortisol dalam tubuh.

\section{SIMPULAN}

1. Ada hubungan yang bermakna antara aktivitas fisik dengan kadar glukosa darah puasa pada Mahasiswa Fakultas Keguruan Ilmu Pendidikan Angkatan 2017-2018 Jurusan Pendidikan Jasmani Kesehatan dan Rekreasi UHO kota Kendari tahun 2019.

2. Tidak ada hubungan yang bermakna antara asupan energi dengan kadar glukosa darah puasa pada mahasiswa Fakultas Keguruan IImu Pendidikan Angkatan 2017-2018 Jurusan 
Pendidikan Jasmani Kesehatan dan Rekreasi UHO kota Kendari Tahun 2019.

3. Tidak ada hubungan yang bermakna antara stres dengan kadar glukosa darah puasa pada mahasiswa Fakultas Keguruan IImu Pendidikan Angkatan 2017-2018 Jurusan Pendidikan Jasmani Kesehatan dan Rekreasi UHO kota Kendari Tahun 2019.

\section{SARAN}

1. Diharapkan kepada mahasiswa Fakultas Keguruan Ilmu Pendidikan Angkatan 2017-2018 Jurusan Pendidikan Jasmani Kesehatan dan Rekreasi UHO Kendari Tahun 2019. Agar lebih sering melakukan aktivitas fisik, memperhatikan asupan energi dan menghindari stres supaya kadar glukosa darah dalam tubuh tetap normal.

2. Diharapkan kepada peneliti selanjutnya untuk dapat melakukan penelitian secara mendalam mengenai faktor-faktor lain yang dapat menyebabkan kadar glukosa darah tidak normal.

\section{DAFTAR PUSTAKA}

1. Who, G., (2016). kadar Glukosa darah puasa pada Penyandang Diabetes Melitus Tipe 2. eJournal kesehatan Indonesia, 3(1). https://doi.org/10.23886/ejki.3.4810.

2. Rudi, A. (2017). Faktor Risiko Yang mempengaruhi Kadar Gula Darah Puasa Pada Pengguna Layanan Laboratorium. Sekolah Tinggi IImu Kesehatan Kapuas Raya Abstrak, 3, 1.

3. Kementerian Kesehatan RI. (2018). Mengenal Jenis Aktivitas Fisik. Direktorat Promosi Kesehatan Dan Pemberdayaan Masyarakat.

4. Parawansa, A. (2018). Pengaruh Aktivitas Fisik Terhadap Kadar Gula Darah Pada Siswa Smk negeri 1 bulukumba (Vol. 2).

4. Kementerian Kesehatan RI. (2018). Mengenal Jenis Aktivitas Fisik. Direktorat Promosi Kesehatan Dan Pemberdayaan Masyarakat.

5. Wilda, L. (2015). Hubungan faktor makanan dengan kadar glukosa darah lansia di desa pesudukuh kecamatan bagor kabupaten nganjuk. 20-26. Jurnal E-Biomedik.

6. Barnes, (2017). hubungan aktifitas fisik dengan kecepatan pemulihan otot Pada Pasien Diabetus Mellitus Tipe 2 di lampung. Jurnal kesehatan. 30-36.

7. Berkat et al. (2018). Faktor-Faktor Yang Berhubungan Dengan Kadar Gula Darah Pada Penderita Diabetes Melitus Tipe 2. 6, 3.

8. Nurayati, L., \& Adriani, M. (2017). Hubungan Aktifitas Fisik dengan Kadar Gula Darah Puasa Penderita Diabetes Melitus Tipe 2. Amerta
Nutrition,

1(2),

80.

https://doi.org/10.20473/amnt.v1i2.6229

9. Fitri dan Wirawanni, Y. 2012. Asupan Energi, Karbohidrat, Serat, Beban Glikemik, Latihan Jasmani dan Kadar Gula Darah pada Pasien Diabetes Mellitus Tipe 2. Fakultas Kedokteran Universitas Diponegoro. Semarang.

10. Sudarsono, N. C. (2015). Indikator Keberhasilan Pengelolaan Aktivitas Fisik pada Penyandang Diabetes Melitus Tipe 2. eJournal Kedokteran Indonesia,3(1).https://doi.org/10.23886/ejki.34 810.

11. Bintanah dan Handarsari. 2012. Asupan Serat dengan Kadar Gula Darah, Kadar Kolesterol Total dan Status Gizi Pada Pasien Diabetus Mellitus Tipe 2 Di Rumah Sakit Roemani Semarang. UNIMUS. Semarang: 290-294

12. Nadia, K. 2015. Hubungan Pengetahuan Terkait Diabetes, Aktivitas Fisik, Konsumsi Pangan Sumber Gula Dengan Glukosa Darah pada Pekerja Garmen Wanita. Fakultas Ekologi Manusia IPB.

13. Sahara, I. (2017). Hubungan Aktivitas Fisik terhadap Kadar Glukosa Darah Puasa Pada Pelajar Di SMA Olahraga Negeri Sriwijaya. Universitas Muhammadiyah Palembang.

14. Sherwood, L. 2012. Fisiologi Manusia dari Sel ke Sistem. EGC: Jakarta. Jurnal Kesehatan, 5(1), 6-11.

15. Mukhti, S.N., 2014. Hubungan asupan energy terhadap kadar glukosa darah puasa.Yogyakarta. Jurnal kedokteran.1-120.

16. Subiyono et al. (2016). Gambaran Kadar Glukosa Darah Metode GOD-PAP (Glucose Oxsidase - Peroxidase Aminoantypirin) Sampel Serum dan Plasma EDTA (Ethylen Diamin Terta Acetat). Jurnal Teknologi Laboratorium, 5(1), 5-8.

17. Suhadi, C. (2020). Hubungan Tingkat Stres Terhadap Kadar Glukosa Darah Pada Manusia Dengan Rentang Umur 19-22 Tahun. eJournal Farmaka, Volume 18 Nomor 1.

18. Azitha, M., Aprilia, D., \& Ilhami, Y. R. (2018). Hubungan Aktivitas Fisik dengan Kadar Glukosa Darah Puasa pada Pasien Diabetes Melitus yang Datang ke Poli Klinik Penyakit Dalam Rumah Sakit M. Djamil Padang. Jurnal Kesehatan Andalas, 7(3), 401. 